\title{
Znajdź to, czego się (nie)spodziewasz. Pisanie/ czytanie dzienników jako poszukiwanie
}

\section{Discover the (Un)Expected: Writing/Reading Journals as an Act of Exploration}

\begin{abstract}
The present paper focuses on several significant issues connected with writing/ reading journals. The author discusses journals, treated as an everyday practice based on obligatory narrativization of experience (as defined by Hannah Arendt), within the ethical horizon demarcated by the philosophy of Paul Ricœur and Charles Taylor and the ideas of David Parker. Parker's argument of immanent ethical nature of journaling is confronted with autobiographical theories developed by Philippe Lejeune, Małgorzata Czermińska, and Magdalena Marszałek. The discussion is supplemented by the indispensable component of gender. The narrative nature of journals becomes a starting point for changing the perspective used in the analysis of journals - from hermeneutic to constructivist, which also finds its reflection in how the subject is shaped in journal entries.
\end{abstract}

Keywords: diaries, identity, narration, experience, ethics

Streszczenie: Niniejszy szkic skoncentrowany jest na kilku ważnych kwestiach związanych z pisaniem/czytaniem dzienników. Dzienniki traktowane jako codzienna praktyka życiowa, oparta na obligatoryjnej narratywizacji doświadczenia (za Hannah Arendt), zostają tu umieszczone w horyzoncie etycznym wyznaczanym przez idee filozoficzne Paula Ricœura, Charlesa Taylora oraz propozycje lekturowe Davida Parkera. Teza tego ostatniego o immanentnej etyczności gestu diarysty zostaje skonfrontowana z teoriami autobiograficznymi Philippe’a Lejeune’a, Małgorzaty Czermińskiej i Magdaleny Marszałek. Dodatkowo rozważania zostają uzupełnione o niezbędny komponent genderowy. Narracyjność w diarystyce staje się również punktem wyjścia do zmiany optyki postrzegania dzienników - od hermeneutycznej po konstrukcjonistyczną, odbijające się także na kształcie podmiotu dziennikowych notatek.

Słowa kluczowe: dzienniki, tożsamość, narracja, doświadczenie, etyka

Dziennik to pamięć. Pozwala osobowości ukonstytuować się w czasie. (...) Za pomocą dziennika tworzymy archiwa naszego życia, które nie zostały przerobione przez naszą pamięć. (...) Tak więc dziennik pozwala zbudować pamięć na fundamencie faktów. 
Pozwala także wyrazić emocje, uczucia, bez ranienia drugiej osoby. Wszystkie rozczarowania, wrogie emocje, konflikty mogą zostać w pewien sposób „zamortyzowane”, złagodzone przez zapisywanie w dzienniku. (...)

Dziennik to sekretne miejsce, w którym możemy wyrazić swój ból, w którym możemy napisać to, czego nie możemy powiedzieć innym. (...) A kiedy wyrazimy na papierze nasze uczucia, lęki, agresję, możemy zacząć się im przyglądać - zastanawiać nad nimi - co nie jest możliwe, jeśli one w nas buzują.

A zatem dziennik pozwala także badać samego siebie i rozważać różne sprawy; dokonywać wyborów, poszukiwać rozwiązań. Czyli zapanować nad swoim życiem ${ }^{1}$.

Przywołana charakterystyka dziennika jako jednego z najważniejszych gatunków literatury dokumentu osobistego (termin Romana Zimanda, łączący dwie perspektywy - literaturoznawczą i socjologiczną ${ }^{2}$ ) sygnalizuje kilka zasadniczych kwestii. Po pierwsze, przypomina, że dziennik nierozerwalnie związany jest z pracą pamięci, w której wydarzenia, emocje, zostały wstępnie opracowane, więc opowieść diarystyczna z założenia pisana z niewielkiego dystansu czasowego bywa traktowana jako nieodległe i (pozornie) wierne odbicie życia. Po drugie, Philippe Lejeune, wskazując na swoistą koncyliacyjność dziennikowych zapisów, podkreślił ich autoterapeutyczny wymiar ${ }^{3}$, przynoszący ukojenie. Po trzecie, badacz, akcentując traktowanie diarystycznych notatek jako przestrzeni ujawniania tajemnic, wskazał ich dialogiczną naturę - na ogół dziennik jest samozwrotny, niemniej gdy zostanie opublikowany, zamienia się w dialog na linii autor/autorka ${ }^{4}$ - czytelnik/czytelniczka. Po czwarte, podkreślając analityczny rys dzienników, Lejeune traktuje dzienniki niczym laboratoria myśli. Elementem spajającym wymienione cechy jest widoczna dynamiczność diarystyki (podlegającej nieustannej transformacji, przy jednoczesnym realizowaniu innego celu - choćby momentalnego scalenia opisywanej egzystencji), zmieniającej się wraz z przekształceniami realiów pozatekstowych. Autobiografia, zanim stanie się tekstem, można powiedzieć, że zaczyna się pisać w życiu - w rozmowach, doświadczeniach, spotkaniach. Pisemna reprezentacja jest jej wersją, niezgodną ze stanem wyjściowym, do którego dostęp zostaje bezpowrotnie utracony,

1 P. Lejeune, M. Rodak, Laboratorium badacza. Rozmowa z Philippem Lejeune’em, „Teksty Drugie" 2018, nr 6, s. 215.

2 Zob. R. Zimand, Diarysta Stefan Ż., Wrocław 1990.

3 Narracja diarystyczna jako element ułatwiający samopoznanie, rozpatrywanie relacji międzyludzkich, jest o tyle istotna, że przypomina, iż oprócz dążenia do życia spełnionego można w zapiskach dokonywać niekoniecznie sprawiedliwych rozliczeń z innymi. Por. M. Wołk, Opowiadanie i narracja w prozie pierwszoosobowej [w:] Praktyki opowiadania, red. B. Owczarek, Z. Mitosek, W. Grajewski, Kraków 2001, s. 51.

${ }^{4}$ Uważam za niezbędne wskazanie, że podmiot diarystyczny różnicowany jest w perspektywie genderowej. 
gdy wydarzenia czy emocje ustają. Nie wolno zapomnieć, że autobiografia, a zatem i dziennik, „to nie jest tekst, w którym ktoś mówi o sobie prawdę, ale tekst, w którym realnie istniejąca osoba twierdzi, że mówi o sobie prawdę"5. W sprytny sposób autor/autorka zawiera z czytelnikiem/czytelniczką pakt, oparty na zaufaniu, czy domniemaniu czyjejś szczerości ${ }^{6}$. Konieczna jest również zgoda na niemożliwą do pełnego zweryfikowania przez czytających autentyczność, wiarygodność intymnej narracji, bazującej na gotowości do przyjęcia za nią odpowiedzialności ${ }^{\top}$.

Powyżej został przedstawiony splot wielu elementów związanych z całością dyskursu diarystycznego, skupiam się na kilku, wynikających zarówno ze słusznych uwag Lejeune’a, jak i oryginalnej propozycji Davida Parkera ze szkicu Narracja autobiograficzna i jezyki dobra. Parker zakłada, że narracja dziennikowa przede wszystkim służy autorom (uzupełniam tę uwagę o autorki; badacz pomija aspekt genderowy ${ }^{8}$ ) do zapisania, lub inaczej, sprawozdania z dążenia do „życia dobrego"' (włączającego komponent etyczny ${ }^{10}$ - od razu zaznaczam, że koncepcja badacza nie ma to nic wspólnego z moralizatorstwem). To pojęcia o tyle atrakcyjne, o ile pojemne, to znaczy każdorazowo zależy od autorskiej perspektywy - profilowanej przez cechy osoby piszącej - oraz od dyspozycji diarysty ${ }^{11}$; Parker zręcznie unika wieloznaczności, wybierając Ricœurowską etykę (równoznaczną z życiem dobrym i dążeniami do niego, przekładającymi się u francuskiego filozofa także na odpowiedzialność za swoje działania) - co jest rozwiązaniem nie rewolucyjnym, niemniej

5 P. Lejeune, M. Rodak, dz. cyt., s. 201.

${ }^{6}$ Kategorię „szczerości” prześledziła w polskiej diarystyce (i epistolografii) Helena Zaworska. Por. taż, Szczerość aż do bólu. O dziennikach i listach, Warszawa 1998, s. 5-7. Na doniosłość intencjonalnej szczerości w autobiografiach wskazywała również Laura Marcus w Auto/biographical Discourses: Criticism, Theory, Practice (Manchester 1994). Zob. L. Anderson, Autobiography, London-New York 2011, s. 2-3.

7 Por. K. Rosner, Narracja, tożsamość i czas, Kraków 2003, s. 46-49.

8 Etyczność jest wpisana w ten typ oglądu literatury podobnie jak w każdy inny. Przyjęcie konkretnej optyki lekturowej zawsze jest gestem etycznym.

9 Zob. P. Ricœur, O sobie samym jako innym, tłum. B. Chełstowski, oprac. i wstęp M. Kowalska, Warszawa 2005. Odsyłam także do dwóch monografii: Marka Drwięgi Paul Ricoeur daje do myślenia (Bydgoszcz 1998) i Grażyny Lubowickiej Sumienie jako poświadczenie. Idea podmiotowości w filozofii Paula Riccura (Wrocław 2000).

${ }^{10}$ Dziennik bywa nie tylko przestrzenią wolności, lecz i kontroli. Philippe Lejeune przypomniał o tym, sięgając po przykład z XIX wieku. Pisanie dzienników zalecano dziewczętom, które nie pozostawały ich jedynymi czytelniczkami, notatki były czytane przez matki, guwernantki. Dziennik z emancypacyjnego stawał się dyscyplinującym. Zob. P. Lejeune, Dziewczęce ,ja”. (O dziennikach panien z XIX wieku) [w:] tegoż, „Drogi zeszycie... ”, „drogi ekranie...”. $O$ dziennikach osobistych, tłum. A. Karpowicz, M. i P. Rodakowie, wybór, wstęp i oprac. P. Rodak, Warszawa 2010, s. 207-208.

${ }^{11}$ D. Parker, Narracja autobiograficzna i jezzyki dobra, tłum. A. Skucińska, „Konteksty Kultury" 2021, t. 18, z. 1, s. 10-13. 
o tyle efektywnym, że powiązanym z zagadnieniem narracyjnej tożsamości ${ }^{12}$, istotnej w myśleniu o dziennikach.

Ich immanentny tożsamościotwórczy aspekt, spowinowacony z ważnymi dla Parkera ustaleniami Charlesa Taylora ${ }^{13}$, domaga się uwzględnienia aspektu etycznego, rozumianego jako myślenie o własnej egzystencji, która polegać ma na dążeniu do dobrostanu, oznaczającego zgodność oczekiwań czy zamierzeń życiowych z ich faktycznym przebiegiem (nierzadko pozornie pozostającym obok kwestii ściśle etycznych, czyli niewskazujących bezpośrednio na etyczne motywacje działań). Czy rzeczywiście tak chętnie publikowane współcześnie (i dawniej) dzienniki pisarzy, poetek, uczonych, na przykład Jarosława Iwaszkiewicza, Julii Hartwig, Sławomira Mrożka, Agnieszki Osieckiej, Jana Józefa Szczepańskiego, Jerzego Pilcha, Hanny Świdy-Ziemby, Anny Kowalskiej, Wiktora Woroszylskiego, Tadeusza Sobolewskiego to świadectwa ${ }^{14}$ właśnie takich starań? Czy ich wartość (już wyjściowo wysoka jako cennych dokumentów życia) wzrasta, jeśli zostanie uzupełniona o silnie eksponowany, po Taylorowsku rozumiany, aspekt etyczny ${ }^{15}$ ? Diarystyka, czyli transpozycja i komentarz do egzystencji, jest wielopiętrowym zapisem starań o spełnienie marzeń czy aspiracji, unikania tego, co postrzegane jako niekorzystne lub ograniczające.

12 Według Ricœura etyka w trojaki sposób przyczynia się do kształtowania narracyjnej tożsamości, opierając się na opowieści (mającej niezbywalny walor etyczny): „„zacunkowi dla siebie odpowiada pojęcie tożsamości narracyjnej, przez które definiuję spójność osoby w postrzeganiu życia człowieka. Osoba określa samą siebie w czasie jako narracyjną jedność życia. Po drugie, element odmienności, który (...) figuruje (...) pod nazwą troski o drugiego człowieka, ma swój odpowiednik narracyjny w samej konstytucji tożsamości narracyjnej. Żadna historia życia nie zamyka się sama na sobie, lecz jest spleciona ze wszystkimi historiami życia, w które dany człowiek jest wplątany. (...) Po trzecie, naszkicowane tutaj podejście narracyjne odnosi się zarówno do instytucji, jak i do osób wziętych indywidualnie czy też we wzajemnym oddziaływaniu”. P. Ricour, Osoba: struktura etyczna i moralna, tłum. J. Fenrychowa [w:] Zawierzyć cztowiekowi. Księdzu Józefowi Tischnerowi na sześćdziesiąte urodziny, Kraków 1991, s. 52. Dodatkowo nie do pominięcia jest fakt, że dla Parkera tożsamość zawsze zakłada dążenie do dobra, nierzadko dość kruchego, czyli takiego, które w toku opowiadania raz jest bliższe, a raz oddala się. Jego usytuowanie ma więc naturę dynamiczną, zależną od aktywności podmiotu. Por. Ł. Tischner, Perspektywa etyczna $w$ badaniach nad literatura i religia. Redukcja czy konieczne dopetnienie? [w:] Literatura a religia - wyzwania epoki świeckiej, t. 1: Teorie i metody, red. Ł. Tischner, Ł. Garbol, Kraków 2020, s. 569-572.

13 „Według Taylora tożsamość człowieka wiąże się z ukierunkowaniem na silnie wartościowane dobra. Wiedzieć, kim się jest, to być zorientowanym w tak zwanej przestrzeni moralnej: w przestrzeni zarysowanych powyżej pytań o własne poglądy, o to, jakie istotne dobra lub wartości wytyczają dla nas horyzont znaczenia”. D. Parker, dz. cyt., s. 19. Zob. też: Ch. Taylor, Źródta podmiotowości. Narodziny tożsamości nowoczesnej, tłum. M. Gruszczyński, O. Latek, A. Lipszyc i inni, oprac. T. Gadacz, wstęp A. Bielik-Robson, Warszawa 2001.

${ }^{14} \mathrm{~W}$ rozumieniu literalnym oraz zaproponowanym przez Małgorzatę Czermińską w Autobiograficznym trójkącie. Świadectwie, wyznaniu, wyzwaniu, Kraków 2000.

${ }^{15}$ Nota bene wyraźny w dziennikach religijnych. Por. K. Nadana-Sokołowska, Problem religii w polskich dziennikach intymnych: Stanistaw Brzozowski, Karol Ludwik Koniński, Henryk Elzenberg, Warszawa 2012. 
Czy można odnaleźć Parkerowską etyczność ${ }^{16} \mathrm{w}$ tak interpretacyjnie profilowanych dziennikach? Prymarnie są przecież rekapitulacją poszukiwań samej/ samego siebie przez autorkę/autora (owocujących metodycznym budowaniem narracyjnej tożsamości), choćby na zasadzie metafory drogi, jaką zaproponował Paul Ricœur ${ }^{17}$. Francuski filozof dowodził, że człowiek nie ma bezpośredniego dostępu do tego, kim jest. Zostaje zmuszony do namysłu i/lub refleksji, czyli zaangażowania w rzeczywistość, oznaczającego także opowiadanie o niej. Przydatny bywa tu dziennik, z założenia eklektyczny, zależny od umiejętności pisarskich, zapatrywań światopoglądowych, ambicji autora. Kolejnymi zmiennymi, jakie należy uwzględnić, są: rytm dziennikowych notatek (ich regularność, miejsce w codziennym rozkładzie dnia), tematyka (frekwencja konkretnych zagadnień), sama forma zapisków (długość, potencjalne genologiczne powiązania, uciekanie się do formuły kolażu), autorefleksyjność (specyfika owej introspekcji), metarefleksje związane z ulokowaniem dziennika w codzienności, sposobem jego rozumienia, przyświecającymi mu intencjami. Nie bez znaczenia pozostaje ukształtowanie językowe oraz wszelkie nieregularności w zapisach, świadczące o kluczowych dla „ja” diarystycznego zmianach ${ }^{18}$. Dodatkowo, jak zauważył Paweł Rodak:

Dziennik osobisty może być zasadniczo postrzegany na dwa sposoby: jako tekst bądź dyskurs oraz jako codzienna praktyka piśmienna. W pierwszym przypadku (...) najważniejsza jest treść dziennikowych zapisów i ich struktura językowo-kompozycyjna (to, w jaki sposób dziennik jest skonstruowany jako pewien model tekstu czy typ narracji). W drugim przypadku dziennik to rodzaj indywidualnej praktyki, pewien sposób działania słowem, który sprawia, że w ramach tego działania tekst jest tylko jednym ze składników, obok składnika performatywno-funkcjonalnego (miejsce, jakie zajmuje prowadzenie dziennika w życiu piszącego, funkcje dziennika) oraz materialnego (nośnik dziennika, jego struktura materialna, wygląd ${ }^{19}$.

Traktowanie narracji jako codziennej praktyki nie tylko wskazuje na jej zakorzenienie w życiu, ale także sygnalizuje, że pisanie stanowi jedną z czynności, wpływających na kształt codzienności - zgodnie ze stwierdzeniem Michela de Certeau: „Codzienne praktyki należą do ogromnego zbioru, którego granice są

${ }^{16} \mathrm{~W}$ propozycjach Parkera kryje się supozycja o dążeniu do dobra jako nieodzownej cesze diarystycznych narracji. Zgadzam się z nim w tej kwestii jedynie częściowo. W dziennikach takowe nakierowanie nie musi być wyrażone wprost. Niekiedy pozostaje ono tylko po stronie osoby czytającej jako wybierana (operacyjnie wydolna) siatka interpretacyjna.

${ }^{17}$ Por. M. Drwięga, dz. cyt., s. 23.

${ }^{18}$ Zob. K. Nadana-Sokołowska, dz. cyt., s. 23. Szczegółowo omawia te zagadnienia Paweł Rodak w monografii Między zapisem a literatura. Dziennik polskiego pisarza w XX wieku (Żeromski, Natkowska, Dąbrowska, Gombrowicz, Herling-Grudziński), Warszawa 2011.

${ }^{19}$ P. Rodak, Między zapisem a literaturą..., dz. cyt., s. 29. 
trudne do wytyczenia, a który można określić roboczo jako zbiór procedur. Są to schematy działań oraz manipulacje techniczne" ${ }^{20}$. Zawężając perspektywę de Certeau do mikroskali dziennika, można zauważyć, że gatunek jest przestrzenią zarówno zrygoryzowaną, jak i wyjątkowo elastyczną, co sugeruje, że wymienione przez Rodaka dwa podejścia do dziennika są jednymi z wielu - wyznaczają ramy, wewnątrz których istnieją liczne pośrednie formy diarystyczne.

Dziennik, nieszablonowe jednorazowe wydarzenie, jest unikatowy, podobnie jak unikatowy i wyjątkowy jest jego autor ${ }^{21}$ lub autorka. Każda lektura diarystycznych zapisków to spotkanie - które modelują elementy powtarzalne (związane z cechami dziennika jako gatunku) i jednorazowe - jak również doświadczenie podwójnie idiomatyczne (ze względu na niepowtarzalność autora/ autorki i czytających/interpretujących). O wyjątkowości diarystycznej narracji decyduje jej znacznie eklektyczna natura, ale też pomijana, na pierwszy rzut oka niewidoczna właściwość, związana z samym aktem pisania dziennikach: „to konkretna czynność polegająca na zbudowaniu własnej przestrzeni tekstu mającego władzę nad zewnętrznością, z której go najpierw wyizolowano"22. Podmiot dziennikowy jest jednocześnie ekscentryczny - ponieważ dystans (nawet niewielki), dzielący go od opisywanych kwestii, jest konieczny do werbalnego zbudowania przestrzeni, w której obrębie będzie ulokowany - oraz introwertyczny. Nie bywa statyczny(-na) ani bierny(-na); działa, ale i tematyzuje, zarówno ową czynność, jak i to, co przydarzyło się mu/jej wcześniej, zgodnie z tezami Hannah Arendt:

Działanie pozbawione mowy nie byłoby już działaniem, ponieważ nie byłoby już tego, kto działa, aktora [actor], a ten, kto działa, sprawca czynów, jest możliwy tylko wtedy, gdy jest jednocześnie mówcą wypowiadającym słowa. Działanie, które on rozpoczyna, jest odsłaniane przez ludzki świat i mimo iż jego czyn może być postrzegany w swojej brutalnej fizycznej zjawiskowości bez towarzyszenia słów, staje się istotny dopiero przez wypowiedziane słowo, w którym on sam rozpoznaje siebie jako działającego, ogłaszając, co czyni, co uczynił i co zamierza uczynićc ${ }^{23}$.

Stwierdzenia Arendt akcentujące działanie i mowę, na diarystycznym gruncie, nie tylko dookreślają status autora-narratora-bohatera, lecz i wyjaśniają jego paradoksalny retroaktywny aspekt, nierozerwalnie złączony z terá́niejszością aktu pisania. Przeszłość utrwalana jest w teraźniejszości. Dodatkowo na plan

${ }^{20}$ M. de Certeau, Wynaleźć codzienność. Sztuki dziatania, tłum. K. Thiel-Jańczuk, Kraków 2008, s. 45.

${ }^{21}$ Por. tamże, s. 115.

22 Tamże, s. 135.

${ }^{23}$ H. Arendt, Kondycja ludzka, tłum. A. Łagodzka, Warszawa 2000, s. 197. Przed zamilknięciem jako rodzajem utraty tożsamości, ale i anulowaniem dążenia do dobra ostrzegał także Taylor: „Bez artykulacji stracilibyśmy wszelki kontakt z dobrem, jakkolwiek byśmy je pojmowali. Przestalibyśmy być ludźmi”. Ch. Taylor, dz. cyt., s. 191. 
pierwszy zostaje wydobyty tożsamościotwórczy charakter działania-pisania ${ }^{24}$, najciekawszy, najbardziej złożony element dziennikowej narracji.

Nie do pominięcia jest również historia pojawienia się, ewolucji i rosnącej poczytności dzienników - pozwala bowiem na uświadomienie, że są ściśle zależne od kontekstów kulturowych (do czego jeszcze wrócę), potrzeb czytelniczych, stopniowego inkorporowania do dzienników cech literatury fikcjonalnej, przemiany napisanego ręcznie, na maszynie, w komputerze dokumentu w książkę. Rodak wzrost zainteresowania praktykami diarystycznymi lokuje w wieku XIX ${ }^{25}$. Kształtująca się nowoczesność sprzyjała skupianiu się na jednostkowości, szukającej języka do opowiedzenia o sobie. Elżbieta Wichrowska przesuwa moment inicjalny polskiej diarystyki o co najmniej kilkadziesiąt lat wstecz, do wieku XVIII, optując za traktowaniem go jako stopniowo dokonującego się zwrotu intymistycznego ${ }^{26}$, polegającego nie tylko na rekonstruowaniu zdarzeń, relacjonowaniu przemyśleń, lecz i na próbach określenia tego, „co się we mnie dzieje”27. W dzienniku ważne zaczęło być opisywanie emocji, uczuć, afektów - przeżycia stały się tak samo istotne jak fakty, pogłębiały się świadomość genologiczna i namysł nad specyfiką pisania. Postępujące klarowanie się diarystycznego dyskursu powiązane było z rosnącą świadomością zależności pomiędzy życiem a opowieścią o nim.

Wzajemne powiązanie nie oznacza zero-jedynkowego przekładania się życia na notatki dziennikowe. Czytając dzienniki - nieważne, czy pisane w XIX czy XX wieku - należy unikać pułapki przekonania, że notatki są lustrzanym odbiciem wydarzeń, które stały się ich kanwą; są interpretacjami, nie relacjami. Prawda w dzienniku jest złożona i zapośredniczona, stale oscyluje między dwiema reprezentacjami - historyczną i literacką ${ }^{28}$. Spora liczba wewnętrznych kombinacji w wyznaczanej w ten sposób przestrzeni owocuje wydzieleniem trzech rodzajów diarystycznej prawdy: wydarzenia (odnoszącej się do wydarzeń, możliwej do zweryfikowania), doświadczenia (immanentnie związanej z osobą

${ }^{24}$ Na podobny trop wskazał Ricœur: „Co uprawnia do uznawania, że podmiot działania pozostaje ten sam przez całe jego życie rozciągające się od narodzin do śmierci? Odpowiedź może być tylko narracyjna. Odpowiedzieć na pytanie »kto?«, jak zdecydowanie twierdziła Hannah Arendt, to opowiedzieć historię życia. Historia opowiedziana mówi o kto działania. Tożsamość kto jest zatem jedynie tożsamością narracyjną". P. Ricœur, Czas i opowieść, t. 3: Czas opowiedziany, tłum. U. Zbrzeźniak, Kraków 2008, s. 353.

${ }^{25}$ Zob. tamże, s. 30-31.

${ }^{26}$ Por. E. Wichrowska, Twoja śmierć. Początki dziennika intymnego w Polsce na przetomie XVIII i XIX wieku, Warszawa 2012, s. 13-15. Badaczka stawia mocną tezę: „o narodzinach intymistyki diariuszowej również na naszej perspektywie kulturowej, w tym językowej, można mówić jeśli nie w perspektywie końca XVIII, to na pewno początków XIX. Hipoteza o blisko 100-letnim opóźnieniu w stosunku do kultury zachodnioeuropejskiej jest nie do utrzymania”. Tamże, s. 21.

27 Tamże, s. 15.

${ }^{28}$ Por. P. Rodak, Prawda $w$ dzienniku pisarza [w:] tegoż, Między zapisem a literaturą..., dz. cyt., s. 103-106. 
piszącą - opartej na tym, co zapisane lub niemożliwe do wyartykułowania) i rzeczywistości (miewającej charakter epifanijny, wykraczającej poza jednostkowość autora czy autorki ${ }^{29}$. W perspektywie złożonej dziennikowej prawdy nieustannie należy mieć na uwadze specyfikę (umownej) prawdy paktu autobiograficznego Lejeune'a oraz tak istotną dla Parkera Taylorowską zasadę najlepszego objaśnienia ${ }^{30}$. Znaczeniowo zbliżona do doświadczenia (zasadniczego budulca narracji) jest równoznaczna z takim sposobem interpretowania zdarzeń, jaki byłby maksymalnie zbliżony do tego, który zostałby zaproponowany przez diarystyczny podmiot ${ }^{31}$. Jest więc zarówno narzędziem opisu (po stronie autora lub autorki), jak i narzędziem interpretacyjnym (po stronie czytających).

Połączenie wyżej wymienionych elementów sugeruje, że pisanie dzienników nie tylko jest specyficznym sprawozdaniem z życia dobrego, lecz przede wszystkim permanentnym dążeniem do „zapisania siebie” 32 przez diarystę. I to jest jeden z najciekawszych aspektów dziennikopisarstwa, decydujący także o atrakcyjności czytelniczej (czy interpretacyjnej) gatunku, w którym oprócz fluktuacji między tym, co idiomatyczne, a tym, co do jakiegoś stopnia uniwersalne, istotne staje się uchwycenie siebie piszącego/piszącej w zasadniczej niepowtarzalności (ale i pewnej ciaggłości). To działanie jest etycznie ${ }^{33}$ podbudowane, owa etyczność ma w przeważającej mierze charakter wsobny, niekiedy wręcz egotyczny, implikujący utrwalenie siebie ponad upływającym czasem - właśnie dzięki sile narracji, bowiem:

Zdaniem Taylora (...) człowiek, jako language animal, zdolny jest do doświadczania tylko i wyłącznie w wymiarze językowym, tylko wtedy rzeczywiście wie, co przeżywa. Po drugie, narracyjne użycie języka sprawia, że nasz sposób przeżywania staje się plastyczny i podatny na zmiany w trakcie nabywania nowego słownika.

${ }^{29}$ Zob. tamże, s. 116-124.

${ }^{30}$ Zob. D. Parker, dz. cyt., s. 21. Taylor następująco wyjaśnia jego działanie: „Pojęcia, które dobieramy, muszą mieć sens w całym zespole różnych sposobów użycia, zarówno wyjaśniających, jak i życiowych. Pojęcia niezbędne dla tego drugiego są częścią opowieści, która najlepiej nas charakteryzuje, chyba że (i do czasu gdy) będziemy mogli zastąpić je pojęciami bardziej przenikliwymi. Wynik owego dążenia do większej przenikliwości przedstawia najlepsze z możliwych w danym czasie objaśnień (...). Najlepsze objaśnienie w powyższym sensie odznacza się największą siłą. Pozwolę sobie nazwać to stwierdzenie zasadą NO”. Ch. Taylor, dz. cyt., s. 116.

${ }^{31}$ Por. A. Bielik-Robson, Wstęp. My, romantycy-źródta romantycznego modernizmu Charlesa Taylora [w:] Ch. Taylor, dz. cyt., s. XXIX.

${ }^{32}$ Kwestia „zapisywania siebie” jest bardziej złożona w dziennikach holokaustowych, o czym pisali Jacek Leociak w Tekście wobec Zagtady. O relacjach z getta warszawskiego (pierwodruk Wrocław 1997), Aleksandra Ubertowska w Holokauście. Auto(tanato)grafiach (Warszawa 2014) czy Justyna Kowalska-Leder w Doświadczeniu Zagtady z perspektywy dziecka w polskiej literaturze dokumentu osobistego (Wrocław 2009).

33 „Wiedzieć, kim się jest, znaczy zarazem: być zorientowanym w przestrzeni moralnej, przestrzeni, w której pojawiają się pytania o to, co dobre, a co złe, co warto robić, a czego nie, co ma sens i wagę, co zaś jest nieistotne i drugorzędne”. Ch. Taylor, dz. cyt., s. 54. 
(...) Po trzecie, język narracji pozwala jednostce usytuować się w dobrze zdefiniowanym horyzoncie etycznym ${ }^{34}$.

Ten efektywny, choć skomplikowany, mechanizm trafnie opisuje Zofia Nałkowska:

Jedynym powodem pisania u mnie jest zawsze chęć zatrzymania życia, ustrzeżenia go przed zgubą i zniszczeniem. Ponieważ najtrudniej jest mi zapisywać zdarzenia, opowiadać jakieś cudze sprawy, wychodzi mi więc na to, że ostatecznie tylko utrwalam siebie ${ }^{35}$.

Przytoczony passus tłumaczy diarystyczne dążenia nie tylko autorki Granicy, z powodzeniem można go odnieść do innych dzienników - zawsze (choć niekoniecznie to główna motywacja) nakierowanych na stworzenie specyficznej alternatywnej wersji życia, tożsamości diarysty lub diarystki. Dziennik (podobnie jak autobiografia sensu largo) jest autoprezentacją, niekiedy skrzętnie maskowaną, ciągle podtrzymywaną przez wewnątrznarracyjną grę tożsamościotwórczych elementów. Tym samym myślenie o dziennikach od ujęcia Lejeune’a, hermeneutycznej ${ }^{36}$ narracyjnej tożsamości Ricœura przesuwa się ku konceptom konstruktywistycznym ${ }^{37}$, przyczyniających się do przeorientowania postrzegania literatury dokumentu osobistego. Wyjaśniła to precyzyjnie Magdalena Marszałek:

Ujęcia autobiografizmu, które opierają się nie na modelach reprezentacji, lecz konstrukcji, unaoczniając performatywność autobiograficznego pisania: autobiograficzne narracje są nie tyle odbiciem „ja” i jego doświadczenia, ile efektywnym instrumentem podmiototwórczych operacji ${ }^{38}$.

Konstruktywizm w badaniach literatury dokumentu osobistego wymusza większą koncentrację na tekście niż na autorze czy autorce, zamienia działanie na performowanie (czyli wywoływanie realnych zmian, odgrywanie tego, co znane, w sposób nieszablonowy, bo każdorazowo niepowtarzalny ze względu na

${ }^{34}$ A. Bielik-Robson, dz. cyt., s. XXXIV.

${ }^{35}$ Z. Nałkowska, Dzienniki, t. 5: 1939-1944, oprac., wstęp i kom. H. Kirchner, Warszawa 1996, s. 423.

36 Warto też zaznaczyć, że dążenie do życia dobrego samo w sobie ma charakter hermeneutyczny. Zob. Ł. Tischner, dz. cyt., s. 569.

${ }^{37}$ Zob. Konstruktywizm w badaniach literackich. Antologia, red. E. Kuźma, A. Skrendo, J. Madejski, Kraków 2006.

${ }^{38}$ M. Marszałek, „Życie i papier”. Autobiograficzny projekt Zofii Natkowskiej „Dzienniki” 1899-1955, wstęp G. Ritz, Kraków 2004, s. 15. Marszałek odwołuje się do interesujących rozwiązań zaproponowanych przez Leigh Gilmore, która akcentuje konstruktywistyczną naturę podmiotu autobiograficznego. Zob. L. Gilmore, Autobiographics: A Feminist Theory of Women's Self-Representation, Ithaca-London 1994. 
niepowtarzalność osoby performującej). Praktyka diarystyczna potwierdza bycie praktyką życiową (realizuje rozumienie dziennika właśnie jako czynności i egzystencjalnej modalności zaproponowane przez Lejeune’a). Innymi słowy, konstruktywizm zmienia optykę postrzegania autobiografii:

idea performatywności autobiograficznego pisania (pisanie samego/samej siebie) wykracza poza strukturę tekstu i ogniskuje się wokół aktu pisania oraz jego konstytutywnych dla piszącego ,ja” (w tym empirycznych) efektów ${ }^{39}$.

Podmiot dziennikowy w tej perspektywie jest ustanawiany, dynamizowany, jego żywiołem staje się zmienność, napędzana dzięki przyrostowi dziennikowych notatek, których kształt zależny nie tylko od dyspozycji pisarskich, ale i kontekstów kulturowych. Stwierdzenie chociaż oczywiste, warte jest podkreślenia gdy jest pomijane, zatracona zostaje idiomatyczność diarystycznych zapisów, co prowadzi do interpretacyjnych nadużyć, a to kłóci się z etycznym trybem odczytań. Uwaga dotyczy wszystkich poziomów autobiograficznych narracji wyznaczanych przez podmiot, pozornie monolityczny, a w rzeczywistości czterodzielny. Pierwszy element to „ja rzeczywiste/historyczne” (czyli autor/autorka żyjący/żyjąca w danym momencie historycznym), drugi ,ja opowiadające” (czyli narrator/narratorka autobiografii), trzeci „ja opowiedziane” (czyli to, które powstaje w tekście i następnie jest interpretowane), ostatni, czwarty „ja ideologiczne zwane też kulturowym" (ulokowane niejako ponad trzema wcześniej wymienionymi; oznacza zestaw identyfikacji tożsamościowych, jakie autobiograf/ autobiografka ma do dyspozycji ze względu na swoje usytuowanie społeczne, klasowe, ekonomiczne itp. ${ }^{40}$. Gatunki autobiograficzne również podlegają kulturowym modyfikacjom, o czym przypomniała Celeste Schenk ${ }^{41}$. Podobnie jak Sidonie Smith i Julia Watson, akcentująca, że doświadczenie diarystyczne to konstrukt kulturowy ${ }^{42}$, dlatego każdorazowo należy brać go pod uwagę i zastanowić się, czy na przykład narzędzia teoretyczne wypracowane w obrębie jednej z kultur mogą być adekwatnie zastosowane do tekstów powstałych w obrębie innych. Heterogoniczność gatunkowa dziennika idzie w parze $\mathrm{z}$ heterogenicznością tematyczną, wyznaczającą także trajektorie interpretacyjne.

Przeniesienie konstruktywizmu z poziomu genologii na podmiot diarystyczny czyni tekst przestrzennym i złożonym. Sądzę, że to najbardziej intrygujący aspekt pisarstwa dziennikowego - obserwowanie, jak kształtowana jest zawsze już narracyjna tożsamość podmiotu stanowiącego rezultat łączenia

${ }^{39}$ M. Marszałek, dz. cyt., s. 16.

${ }^{40}$ S. Smith, J. Watson, Reading Autobiography: A Guide for Interpreting Life Narratives, Minneapolis 2001, s. 58-64. Jedne z najważniejszych badaczek autobiografii, akcentując niejednolitość podmiotu literatury dokumentu osobistego, nie tylko wskazywały na jego złożoność, ale także uwrażliwiały na jego zależność od uwarunkowań pozatekstowych.

${ }^{41}$ Por. L. Anderson, dz. cyt., s. 9-10.

${ }^{42}$ Por. S. Smith, J. Watson, dz. cyt., s. 25-47. 
i wzajemnego modyfikowania elementów historycznych, obyczajowych, ideologicznych, literackich, etycznych. Kompozycja dziennika staje się „,kompozycją istnienia" ${ }^{43}$ - każdorazowo idiomatycznego, nieprzerwanie negocjującego swoje granice, poszukującego najbardziej adekwatnych dla siebie środków wyrazu. Dlatego też czytanie zapisków diarystycznych wymaga szacunku i życzliwości, co jest zbieżne z propozycją trybu lekturowego zaproponowanego przez Lejeune’a. Czytanie życzliwe (czyli etyczne) nade wszystko oznacza akceptację autora/autorki, jest również przedsięwzięciem z gruntu prywatnym, intymnym, wymagającym dyskrecji ${ }^{44}$ - bywa swoistym przejmowaniem części cech dziennikopisarza czy dziennikopisarki. Należy przy tym unikać przechwytywania i zawłaszczania ze względu na wymienione już konteksty (szczególnie genderowe) budujące podmiot dziennikowy. Pisanie/czytanie ma płeć, wpływająca także na specyfikę gatunków autobiograficznych. Stąd też tożsamościotwórcze poszukiwania diarystów i diarystek są zawsze warunkowane przez kulturowe koncepcje rozumienia męskości, kobiecości (w różnym stopniu) konstruktywistyczne bądź esencjalistyczne (zatrzymując się przy podstawowych podziałach). Niekoniecznie więc na plan pierwszy wysuwa się „dążenie do życia dobrego", lecz samo zapisanie przebiegu życia (nota bene, zapisać znaczy nadać sens, czyli wykonać ruch ku dobru ${ }^{45}$ ). Jego nieprzewidywalność przekłada się na nieprzewidywalność lektury, podczas której często znajduje się w diarystycznych notatkach nie to, czego się szukało - co decyduje o stałej atrakcyjności dzienników. Ich lektura stale zaskakuje, wymyka się również interpretacjom generowanym przez wybrane metody badawcze. Jedno jest pewne (tu spotykają się Taylor, Parker, Ricœur, Lejeune, Gilmore, Marszałek, Smith i Watson):

Akt opowiadania scala podmiotowość. Aby określić jakąś osobę, nie wystarczy sam gest nazwania. Tylko w opowieści o życiu jawi się ona jako niepowtarzalna i niezmienna (ipse), funkcjonująca w wymiarze pragmatycznym (podmiot działań) oraz w wymiarze etycznym (podmiot odpowiedzialny wobec Innego, realizujący się w spełnieniu obietnicy). (...) W praktyce opowiadania, które ujmuje człowieka w różnych stanach i etapach, tożsamość danej osoby ujawnia swą dynamikę. Jaźń, to, co jest mną (soi-même), może odsłonić się tylko w konfiguracji narracyjnej ${ }^{46}$.

Wzmiankowana wyżej konfiguracja nierzadko bywa zdumiewająca. A etyczność pozwala ową rewelację nie tylko dostrzec, ale także spróbować z empatią zrozumieć.

${ }^{43}$ Fraza zaczerpnięta z tytułu szkicu o dziennikach Marii Dąbrowskiej autorstwa Marty Wyki. Zob. M. Wyka, Niecierpliwość krytyki. Recenzje i szkice z lat 1961-2005, Kraków 2006.

${ }_{44}$ Zob. P. Lejeune, Napisać swoje życie. Droga od paktu autobiograficznego do dziedzictwa autobiograficznego, tłum. A. Słowik, M. Sakwerda, Wrocław 2017, s. 67.

45 Por. Ł. Tischner, dz. cyt., s. 573.

${ }^{46}$ Z. Mitosek, Hermeneuta i autobiografia, „Teksty Drugie” 2002, nr 2, s. 140. 


\section{Bibliografia}

Anderson L., Autobiography, London-New York 2011.

Arendt H., Kondycja ludzka, tłum. A. Łagodzka, Warszawa 2000.

Bielik-Robson A., Wstęp. My, romantycy - źródta romantycznego modernizmu Charlesa Taylora [w:] Ch. Taylor, Źródta podmiotowości. Narodziny tożsamości nowoczesnej, tłum. M. Gruszczyński, O. Latek, A. Lipszyc i inni, oprac. T. Gadacz, wstęp A. Bielik-Robson, Warszawa 2001.

Certeau M. de, Wynaleźć codzienność. Sztuki dziatania, tłum. K. Thiel-Jańczuk, Kraków 2008.

Czermińska M., Autobiograficzny trójkąt. Świadectwo, wyznanie, wyzwanie, Kraków 2000.

Drwięga M., Paul Ricœur daje do myślenia, Bydgoszcz 1998.

Gilmore L., Autobiographics. A Feminist Theory of Women's Self-Representation, Ithaca-London 1994.

Konstruktywizm w badaniach literackich. Antologia, red. E. Kuźma, A. Skrendo, J. Madejski, Kraków 2006.

Kowalska-Leder J., Doświadczenie Zagtady z perspektywy dziecka w polskiej literaturze dokumentu osobistego, Wrocław 2009.

Lejeune P., Dziewczęce „ja”. (O dziennikach panien z XIX wieku) [w:] tegoż, „Drogi zeszycie... ”, „drogi ekranie... ”. O dziennikach osobistych, tłum. A. Karpowicz, M. i P. Rodakowie, wybór, wstęp i oprac. P. Rodak, Warszawa 2010.

Lejeune P., Napisać swoje życie. Droga od paktu autobiograficznego do dziedzictwa autobiograficznego, tłum. A. Słowik, M. Sakwerda, Wrocław 2017.

Lejeune P., Rodak M., Laboratorium badacza. Rozmowa z Philippem Lejeunéem, „Teksty Drugie” 2018, nr 6.

Leociak J., Tekst wobec Zagtady. O relacjach z getta warszawskiego, Wrocław 1997. Lubowicka G., Sumienie jako poświadczenie. Idea podmiotowości w filozofii Paula Ricoura, Wrocław 2000.

Marcus L., Auto/biographical Discourses: Criticism, Theory, Practice, Manchester 1994.

Marszałek M., „Życie i papier”. Autobiograficzny projekt Zofii Natkowskiej „Dzienniki”1899-1955, wstęp G. Ritz, Kraków 2004.

Mitosek Z., Hermeneuta i autobiografia, „Teksty Drugie” 2002, nr 2.

Nadana-Sokołowska K., Problem religii w polskich dziennikach intymnych: Stanistaw Brzozowski, Karol Ludwik Koninski, Henryk Elzenberg, Warszawa 2012.

Nałkowska Z., Dzienniki, t. 5: 1939-1944, oprac., wstęp i koment. H. Kirchner, Warszawa 1996.

Parker D., Narracja autobiograficzna i języki dobra, tłum. A. Skucińska, „Konteksty Kultury" 2021, t. 18, z. 1.

Ricœur P., Czas i opowieść, t. 3: Czas opowiedziany, tłum. U. Zbrzeźniak, Kraków 2008. 
Ricœur P., O sobie samym jako innym, tłum. B. Chełstowski, oprac. i wstęp M. Kowalska, Warszawa 2005.

Ricœur P., Osoba: struktura etyczna i moralna, tłum. J. Fenrychowa [w:] Zawierzyć człowiekowi. Księdzu Józefowi Tischnerowi na sześćdziesiąte urodziny, Kraków 1991.

Rodak P., Między zapisem a literatura. Dziennik polskiego pisarza w XX wieku (Żeromski, Natkowska, Herling-Grudziński), Warszawa 2011.

Rodak P., Prawda w dzienniku pisarza [w:] Między zapisem a literatura. Dziennik polskiego pisarza w XX wieku (Żeromski, Natkowska, Herling-Grudziński), Warszawa 2011.

Rosner K., Narracja, tożsamość i czas, Kraków 2003.

Smith S., Watson J., Reading Autobiography: A Guide for Interpreting Life Narratives, Minneapolis 2001.

Taylor Ch., Źródta podmiotowości. Narodziny tożsamości nowoczesnej, tłum. M. Gruszczyński, O. Latek, A. Lipszyc i inni, oprac. T. Gadacz, wstęp A. Bielik-Robson, Warszawa 2001.

Tischner Ł., Perspektywa etyczna w badaniach nad literatura i religia. Redukcja czy konieczne dopetnienie? [w:] Literatura a religia - wyzwania epoki świeckiej, t. 1: Teorie i metody, red. Ł. Tischner, Ł. Garbol, Kraków 2020.

Ubertowska A., Holokaust. Auto(tanato)grafiach, Warszawa 2014.

Wichrowska E., Twoja śmierć. Początki dziennika intymnego w Polsce na przetomie XVIII i XIX wieku, Warszawa 2012.

Wołk M., Opowiadanie i narracja w prozie pierwszoosobowej [w:] Praktyki opowiadania, red. B. Owczarek, Z. Mitosek, W. Grajewski, Kraków 2001.

Wyka M., Niecierpliwość krytyki. Recenzje i szkice z lat 1961-2005, Kraków 2006. Zaworska H., Szczerość aż do bólu. O dziennikach i listach, Warszawa 1998.

Zimand R., Diarysta Stefan Ż., Wrocław 1990. 